\title{
Coexistence of both Brenner tumor and cystadenofibroma of ovary in a postmenopausal woman: a rare case
}

\section{B. Kalpana*, Soumya Ranjan Panda}

Department of Reproductive Medicine, Guru Hospital, Madurai, Tamil Nadu, India

Received: 22 December 2018

Accepted: 30 January 2019

\section{*Correspondence:}

Dr. B. Kalpana,

E-mail: balamurugan_kalpana@rediffmail.com

Copyright: $($ ) the author(s), publisher and licensee Medip Academy. This is an open-access article distributed under the terms of the Creative Commons Attribution Non-Commercial License, which permits unrestricted non-commercial use, distribution, and reproduction in any medium, provided the original work is properly cited.

\begin{abstract}
Brenner tumor, and cystadeno fibroma of ovary are rare varieties of ovarian tumor, characterized by presence of solid components. There are very rare instances where both Brenner tumor and cystadenofibroma coexist in a single patient. A 48-year P1L1, postmenopusal woman presented at Guru hospital, Madurai, with chief complaints of on and off postmenopausal bleeding for 6 months. On ultrasonography there were two simple cysts of ovary measuring 6x 6 $\mathrm{cm}$ on left side and $4 \times 4 \mathrm{~cm}$ on right side. She was managed with total laparoscopic hysterectomy and bilateral salpingoophorectomy. Intraoperatively there was a right ovarian mass of $6 \times 6 \mathrm{~cm}$ size and a left ovarian mass of $4 \times 4$ $\mathrm{cm}$ size. Left ovarian mass reported as benign cystadenofibroma while the right ovarian mass was reported to be brenners tumor on histopathology. As the preoperative imaging are not completely relied for diagnosing these tumors, awareness of the surgeons of these entities is particularly important. The prognosis of both of these tumors is excellent with suitable treatment. They have a very low recurrence risk on compete removal through surgery.
\end{abstract}

Keywords: Brenner tumor, Cystadenofibroma, Frozen section, Salpinoophorectomy

\section{INTRODUCTION}

The ovarian tumors constitutea major burden of morbidity in gynecology practices due to the fact that these tumors may remain asymptomatic for a longer period of time. Brenner tumor, also known as transitional cell tumor, is a rare variety that constitute about 2 to 5 $\%$ of the ovarian tumors. ${ }^{1,2}$ The average age at presentation is 50 years with $71 \%$ of the patients being more than 40 years. $^{3}$ It constitutes $1.4-2.5 \%$ of all ovarian tumors and has a predilection for the postmenopausal woman. Ovarian cystadenofibroma is another uncommon category of benign ovarian tumor containing epithelial and fibrous stromal components and accounting for $1.7 \%$ of all benign ovarian tumors. ${ }^{4}$ There are very rare instances where both Brenner tumor and cystadenofibroma coexist in a single patient. Here authors are presenting such a rare case where authors incidentally found both these tumors in a postmenopausal lady.

\section{CASE REPORT}

A 48-year P1L1, postmenopusal woman presented at Guru hospital, Madurai, with chief complaints of on and off postmenopausal bleeding for 6 months. Her general physical and systemic examinations were within normal limits. On bimanual examination uterus was found to be around 8-week size, a mobile mass of size $6 \times 6 \mathrm{~cm}$ was found at right fornix and also authors could find fullness in left fornix. On ultrasonography her endometrial thickness was found to be $11 \mathrm{~mm}$. There were two simple cysts of ovary measuring $6 \times 6 \mathrm{~cm}$ on left side and $4 \times 4 \mathrm{~cm}$ on right side. Endometrial biopsy reported to be proliferative endometrium. CA125 was $26 \mathrm{U} / \mathrm{ml}$. She was 
managed with total laparoscopic hysterectomy and bilateral salpingoophorectomy. Intraoperatively there was a right ovarian mass of $6 \times 6 \mathrm{~cm}$ size and a left ovarian mass of $4 \times 4 \mathrm{~cm}$ size (Figure 1 and Figure 2).

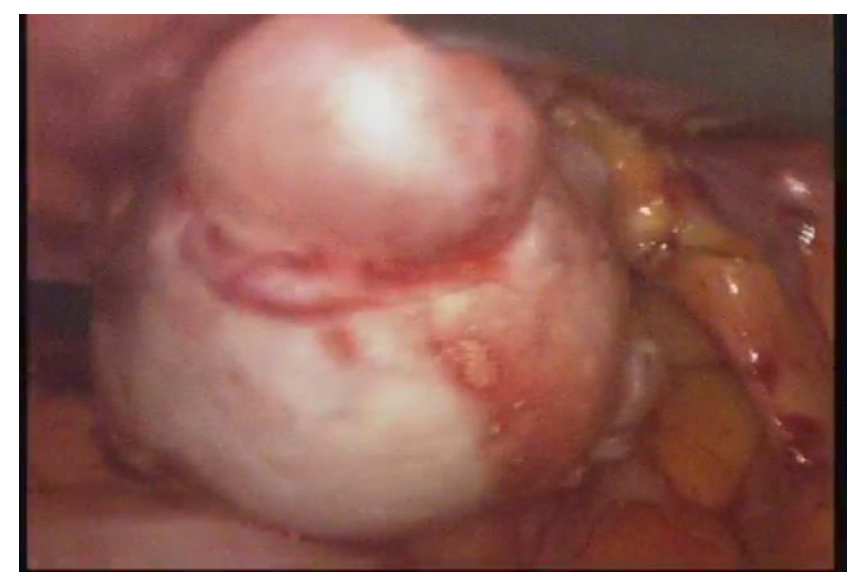

Figure 1: Intra operative image of Brenner tumor.

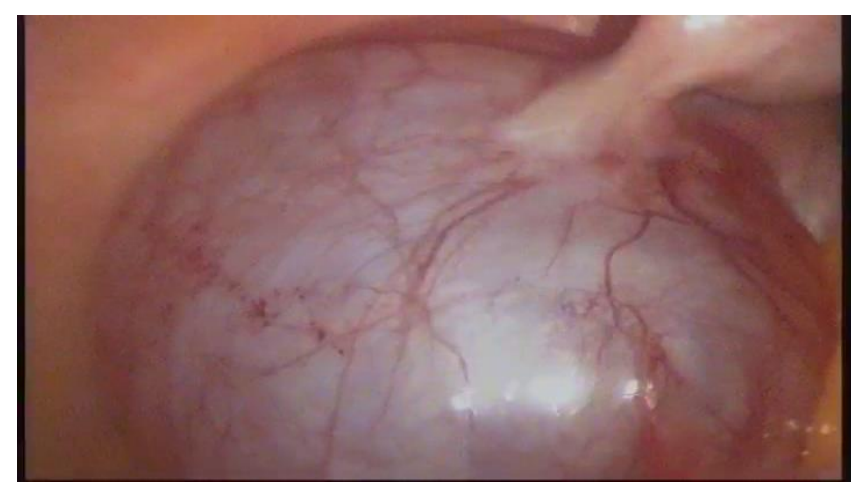

Figure 2: Intra operative image of cystadenofibroma.

On cut section both cysts found to contain solid components. Histopathology of the right sided mass revealed the epithelial cells to be ovoid to polygonal and had pale cytoplasm and oval nuclei. Some of the nuclei had central longitudinal groove (coffee bean appearance). All the above features go in favor of benign Brenner tumor of right ovary (Figure 3).

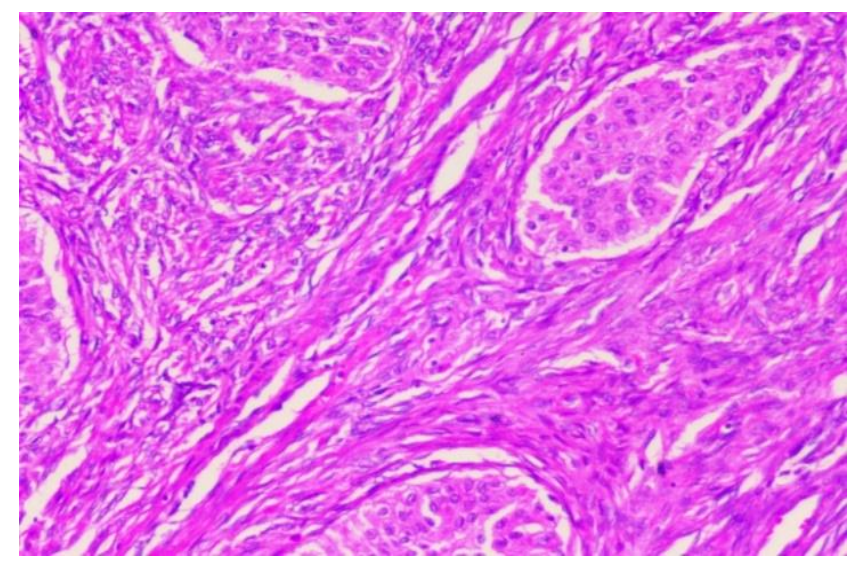

Figure 3: Histopathology image of Brenner tumor.
Left ovarian mass reported as benign cystadenofibroma (Figure 4). No evidence of malignancy. The postoperative period was uneventful, and the patient was discharged with advice of regular follow-up.

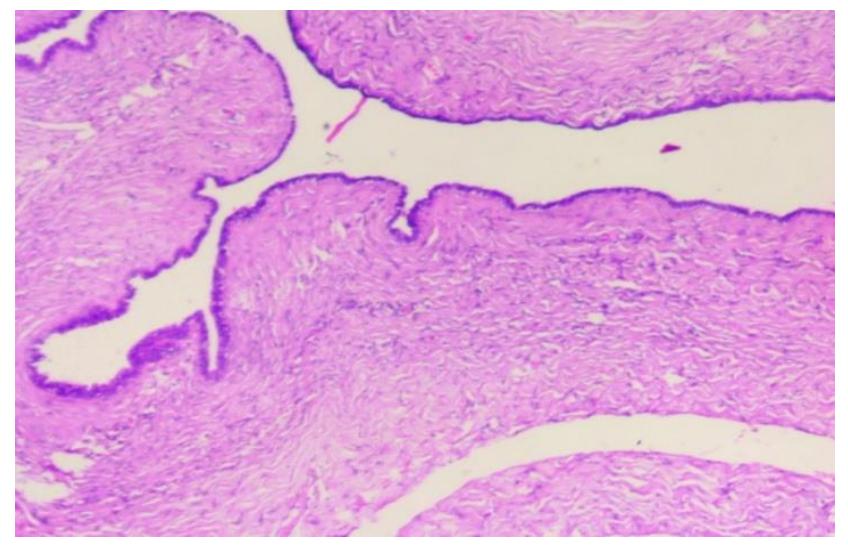

Figure 4: Intra operative image of cystadenofibroma.

\section{DISCUSSION}

Ovarian Brenner tumors are very rare tumors with an unclear etiopathology. According to some studies, Brenner tumors arise from the tubular epithelial cells by transitional metaplasia, while other studies theorerised that the tumoral cells originate from the multipotent cells of the coelomicepithelium, found either on the ovary surface or in some epithelial cysts. As presented by us, these tumors are solid, usually developed on a single ovary, with an ultrasound expression like a parenchymatous tumoral mass located in the pelvis, without intercrossing the uterus. ${ }^{1,5,6}$ Most Brenner tumors are candidates for surgical resection. Incidence of malignant Brenner tumor is very rare. Even malignant Brenner tumors, if diagnosed early, can be managed with complete surgical resection. ${ }^{7}$

Likewise, ovarian cystadenofibroma is another form of uncommon benign ovarian tumor that contains both epithelial and fibrous stromal components. These tumors can be predominantly cystic, complex cystic with variable amounts of solid components or predominantly solid. ${ }^{4,8}$ Preoperative imaging, sometimes misdiagnose these cases as malignant tumors because of their solid component or irregular thick septae. Sonographic features of these tumors are described as uniocular or multilocular cystic structures which may be purely anechoic or contain septations, papillary projections or solid nodules. Blood flow can be detected by color Doppler in half of the cases usually on peripheral cyst wall and in solid areas and sometimes the blood flow impedance can be low and give false-positive results. ${ }^{9}$ Computed Tomography (CT) has a limited value in evaluation of cystadenofibromas as it can cause preoperative misdiagnosis of malignancy. ${ }^{4}$ Even on gross examination at the time of surgery, acystadenofibroma may resemble a malignant tumor. A frozen section diagnosis may be helpful in these cases because a correct diagnosis of cystadenofibroma in the 
operatin groom might save the patient from unnecessary extensive surgery. Cystadenofibroma may occur in reproductive age group and an accurate preoperative diagnosis may help in avoiding extensive surgical procedure. ${ }^{10}$ Luckily in our case both the Brenner tumor as well as the cystadenofibroma were small and rescectable. To the best of our knowledge, till date, there is no such case in literature where both Brenner tumor and ovarian cystadenofibroma coexist in the same patient.

\section{CONCLUSION}

Occurrence of both Brenner tumor and ovarian cystadenofibroma in a single patient is a very rare chance. Ovarian Brenner tumors are solid tumors that are mostly benign and candidates for surgical resection. Although the gross appearance of ovarian cystadenofibromas may resemble a malignant tumor, a frozen-section diagnosis inelective cases may save the patient from unnecessary extensive surgery. The awareness of the surgeons of this entity is particularly important in emergency conditions when frozen diagnosis is not possible. The prognosis of both of these tumors is excellent with suitable treatment. They have a very low recurrence risk on compete removal through surgery.

\section{Funding: No funding sources}

Conflict of interest: None declared

Ethical approval: Not required

\section{REFERENCES}

1. De Cecio R, Cantile M, Collina F, Marra L, Santonastaso C, Scaffa C, Botti G, Losito NS. Borderline Brenner tumor of the ovary: a case report with immunohistochemical and molecular study. J Ovarian Res. 2014;7(1):101.

2. Devouassoux-Shisheboran M, Genestie C, RayCoquard I. [Dualistic classification of epithelial ovarian cancer: is it clinically relevant?] Bull Cancer. 2016;103(3):252-8.

3. Hemalatha AL, Konanahalli P. Bilateral malignant Brenner tumor of ovary. J Obstet Gynecol India. 2005;55(1):81-2.

4. Cho SM, Byun JY, Rha SE, Jung SE, Park GS, Kim $\mathrm{BK}$, et al. CT and MRI findings of cystadenofibromas of the ovary. Eur Radiol 2004;14(5):798-804.

5. Kuhn E, Ayhan A, Shih IM, Seidman JD, Kurman RJ. Ovarian Brenner tumour: a morphologic and immunohistochemical analysis suggesting an origin from fallopian tube epithelium. Eur J Cancer. 2013; 49(18):3839-49.

6. Ingin RJ, Andola SK, Zubair AA. Transitional cell carcinoma of the ovary: case series and review of literature. J Clin Diagn Res. 2014;8(8):FD07-8.

7. Borah T, Bora BD, Mahanta RK and Saikia S. Brenner tumor of ovary: An incidental finding. J Midlife Health. 2011;2(1): 40.

8. Jung DC, Kim SH, Kim SH. MR imaging findings of ovarian cystadenofibroma and cystadenocarcinofibroma: clues for the differential diagnosis. Korean J Radiol. 2006;7(3):199-204.

9. Alcázar JL, Errasti T, Mínguez JA, Galán MJ, García-Manero M, Ceamanos C. Sonographic features of ovarian cystadenofibromas: spectrum of findings. J Ultrasound Med.2001; 20(8):915-9.

10. Takeuchi M, Matsuzaki K, Kusaka M, Shimazu H, Yoshida S, Nishitani $\mathrm{H}$, et al. Ovarian cystadenofibromas: Characteristic magnetic resonance findings with pathologic correlation. J Comput Assist Tomogr. 2003;27(6):871-3.

Cite this article as: Kalpana B, Panda SR.

Coexistence of both Brenner tumor and cystadenofibroma of ovary in a postmenopausal woman: a rare case. Int J Reprod Contracept Obstet Gynecol 2019;8:1204-6. 